\title{
Effectiveness of Progressive Muscle Relaxation on The Complete Opening Time during Normal Labor
}

\author{
Siti Saidah Nasution*, Erniyati Erniyati, Hariati Hariati \\ Department of Maternity and Pediatric Nursing, Faculty of Nursing, Universitas Sumatera Utara, Prof. T. Maas Street Kampus \\ USU, Medan, Indonesia
}

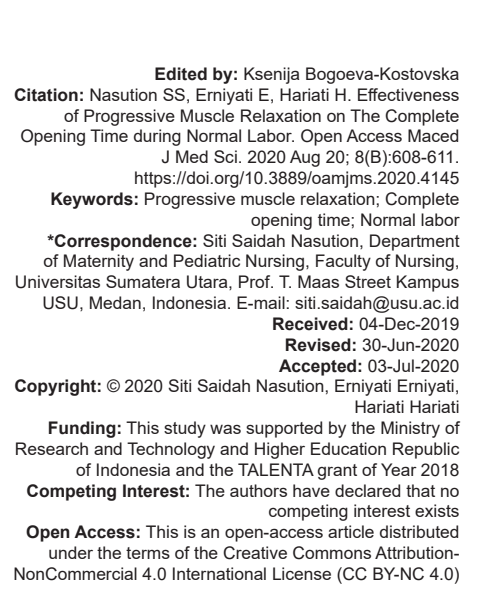

\section{Introduction}

Childbirth is a reproductive stage that a mother will live. Vaginal delivery or normal birth is the process of removing the fetus that occurs in terms of pregnancy (37-42 min), born spontaneously with the presentation behind the head, without complications both mother and fetus [1]. One of the factors that cause anxiety or fear when facing the labor process is a shadow of pain and pain when removing the baby [2]. Pain in labor occurs because of the process of opening and thinning of the cervix and the fetus descending into the birth canal. The pain that arises in labor when 1 is not constant and intermittent, at the opening of $0-3$, the pain is painful and uncomfortable. At opening 4-7, pain is felt slightly piercing [3] states that labor pain is caused by uterine contractions that can increase the activity of the sympathetic nervous system, changes in blood pressure, heart rate, breathing with skin color, and if it is not immediately addressed it will increase anxiety, tension, fear, and stress. If the pain felt by the mother at the $1^{\text {st }}$ time is not overcome, there will be a prolonged labor time. Some studies have shown that in primitive societies experience a longer labor and pain, while those who have advanced $7-14 \%$ have painless delivery and a large proportion of $90 \%$ of deliveries are accompanied by pain [4].

Pain during labor can be controlled through pharmacological methods and non-pharmacological methods. Non-pharmacological methods commonly used to reduce labor pain include relaxation and breathing techniques [3]. Jacobson (1938 in Conrad and Roth, 2007) [5] states that progressive relaxation (deep progressive relaxation) in deep muscle relaxation techniques does not require imagination, perseverance, or suggestion. This technique is based on the belief that the body responds to anxiety that stimulates the mind and events with muscle tension by identifying strained muscles and then reducing tension to get a feeling of relaxation. Relaxation conditions are one of the non-pharmacological methods that can be taught to individuals to reduce feelings of pain. Based on this, progressive muscle relaxation measures are expected to reduce stress both physical and emotional stress on childbirth so that it can reduce the intensity of labor pain experienced. In addition, labor pain can be reduced by relaxing the deep breath by breathing deeply followed by slow breathing (holding inspiration optimally) and exhaling slowly can reduce stress both physical and 
emotional stress, namely, reducing the intensity of pain and reducing anxiety [6]. Yuliati, 2011 [7], who conducted a study by giving breathing relaxation method to 22 mothers who entered the first phase of the active phase in Medan, found a decrease in pain intensity before relaxation of the breath in an average pain intensity of 6.27 while after breathing relaxation, the pain intensity was reduced to be 4.77 . This technique can reduce the sensation of pain and control the intensity of the mother's reaction to pain.

Controlled relaxation and breathing can improve their ability to cope with anxiety and increase their sense of being able to control stress and pain. In addition, relaxation also makes the uterine, placental, and fetal blood circulation smooth so that your baby's oxygen and food needs are met. Smooth blood circulation will also make the muscles associated with the uterus and fetus such as the pelvic muscles, back, and abdomen become limp and sagging. While during labor, relaxation makes the contraction process safe, natural, and smooth [8].

\section{Methods}

This type of quantitative research uses a quasi-experimental method research design with two intervention and control groups. This study was conducted in two groups. The intervention group was given intervention by practicing the progressive muscle relaxation technique at the time of $\mathrm{I}$. The control group was not carried out intervention, then measure the complete opening time from the latent phase to the complete opening $(10 \mathrm{~cm})$. Data analysis was carried out with frequency distribution and presentation, independent t-test to compare the length of complete opening in the two intervention and control groups with a significance level of $5 \%(\alpha=0.05)$.

Table 1: Frequency distribution of mothers giving birth to intervention groups based on demographic characteristics $(n=30)$

\begin{tabular}{lll}
\hline Variable & $\mathrm{n}$ & $\%$ \\
\hline Age & & \\
$\quad$ Risk (<20 and 35 years) & 11 & 37 \\
$\quad$ No risk (20-35 years) & 19 & 63 \\
Obstetric history & & 23 \\
$\quad$ Primi (1) & 7 & 60 \\
$2-3$ & 18 & 17 \\
$\quad>3$ & 5 & \\
Education & 5 & 17 \\
$\quad$ Low (Elementary-junior high school) & 19 & 63 \\
$\quad$ Middle (Senior high school) & 6 & 20 \\
$\quad$ High (University) & & \\
Work & 16 & 53 \\
$\quad$ Housewife & 9 & 30 \\
$\quad$ Government & 5 & 17 \\
$\quad$ Employee & & 73 \\
Action of pain & 22 & 10 \\
$\quad$ Crying & 3 & 7 \\
$\quad$ Screaming & 2 & 10 \\
$\quad$ Swapping & 3 & 13 \\
$\quad$ Praying & & 87 \\
Education of pain & 4 & 100 \\
$\quad$ Yes & 26 & \\
$\quad$ No & 30 & \\
$\quad$ Total & &
\end{tabular}

\section{Results}

The characteristics of maternal respondents who undergo normal childbirth are as shown in Tables 1 and 2 .

Table 2: Distribution of maternal frequency childbirth control groups based on demographic characteristics $(n=30)$

\begin{tabular}{lll}
\hline Variable & $\mathrm{n}$ & $\%$ \\
\hline Age & 13 & 43 \\
$\quad$ Risk (<20 and 35 years) & 17 & 57 \\
$\quad$ No risk (20-35 years) & & \\
Obstetric history & 8 & 27 \\
$\quad$ Primi (1) & 13 & 43 \\
$2-3$ & 9 & 30 \\
$\quad 3$ & & \\
Education & 4 & 13 \\
$\quad$ Low (Elementary-junior high school) & 20 & 67 \\
Middle (Senior high school) & 6 & 20 \\
$\quad$ High (University) & & \\
Work & 15 & 50 \\
$\quad$ Housewife & 8 & 27 \\
$\quad$ Government & 7 & 17 \\
$\quad$ Employee & & \\
Action of pain & 23 & 77 \\
$\quad$ Crying & 2 & 7 \\
Screaming & 3 & 10 \\
Swapping & 2 & 7 \\
Praying & & \\
Education of pain & 5 & 17 \\
$\quad$ Yes & 25 & 83 \\
$\quad$ No & 30 & 100 \\
$\quad$ Total & &
\end{tabular}

Based on Table 3, the length of complete opening time in the intervention group was around 5-6 $\mathrm{h}$ while in the control group, it was around 7-8 h.

Table 3: Distribution of complete opening time for intervention groups and control groups

\begin{tabular}{|c|c|c|c|c|}
\hline \multirow{2}{*}{ Complete opening time (opening 4-10) } & \multicolumn{2}{|c|}{ Intervention } & \multicolumn{2}{|c|}{ Control } \\
\hline & $n$ & $\%$ & $\mathrm{n}$ & $\%$ \\
\hline $1-2 \mathrm{~h}$ & 1 & 3.3 & & \\
\hline $3-4 \mathrm{~h}$ & 4 & 13.3 & 1 & 3.3 \\
\hline $5-6 \mathrm{~h}$ & 16 & 53.3 & 10 & 13.3 \\
\hline $7-8 \mathrm{~h}$ & 7 & 23.3 & 13 & 53.3 \\
\hline $9-10 \mathrm{~h}$ & 2 & 6.6 & 6 & 23.3 \\
\hline Total & 30 & 100 & 30 & 100 \\
\hline
\end{tabular}

Table 4 shows the difference in length of complete opening time of the delivery process in the intervention and control groups. The Mann-Whitney U-test results are $p=0.000$. These results indicate where the value of $p$ $<0.05$, which means that there are significant/significant differences. Progressive muscle relaxation techniques can accelerate complete opening time in labor.

\section{Discussion}

Childbirth is one part of a woman's life cycle that must be lived [9]. This is a stressor for women due to changes in their lives. Pain is a normal reaction to changes that occur and will make someone have

Table 4: The effect of intervention on the length of time for complete opening process in labor process

\begin{tabular}{llll}
\hline Variable & Mean & Std. deviation & p-value \\
\hline Intervention & 5.90 & 1.626 & 0.000 \\
Control & 7.60 & 1.610 & \\
\hline
\end{tabular}


feelings that are not happy or uncomfortable. This is due to the alleged danger or frustration that threatens, endangers the sense of security, balance, or life of an individual or social group. Often, the pain accompanies pregnancy and reaches its peak at delivery [10], [1].

The success of a mother in childbirth is influenced by power, passage, passenger, and psychological factors [3]. Persons who are not adaptive can be a risk in the process of maternal labor such as prolonging the Stage I, parturition is not advanced and is not cooperative in implementing the recommended intervention. An extension in the time of delivery, especially at the time of opening, can threaten the safety of the mother and baby. If in a certain time, the opening of labor in the first stage is not increasing or not progressing then the mother of labor must be immediately referred and carried out collaboration with the doctor and ended with section action.

The results of the study generally show that progressive muscle relaxation techniques can effectively accelerate the process of complete opening time in vaginal delivery. Intervention is done by training mothers to relax by combining deep breathing exercises and tenses certain muscles so that mothers who are undergoing childbirth can be relaxed and calm facing labor [9].

Psychologically, mothers who can adapt to the pain and conditions they are experiencing at this time can relax the muscles in the vagina and speed up the opening process. According to Herodes, 2010 [11], progressive muscle relaxation techniques are deep muscle relaxation techniques that do not require imagination, perseverance, or suggestion. Progressive muscle relaxation techniques focus on a muscle activity by identifying strained muscles and then reducing tension by doing relaxation techniques to get a feeling of relaxation. Progressive muscle relaxation techniques are a relaxation therapy that is given to the client by tensing certain muscles and then relaxation. Progressive relaxation is one way of relaxation techniques combining deep breathing exercises and a series of certain muscle contractions and relaxation [12]. Pain in childbirth is pain in uterine contractions that can result in increased activity of the sympathetic nervous system, changes in blood pressure, heart rate, breathing with skin color, and if not overcome immediately will increase feelings of worry, tension, fear, and stress [3].

Physiology/mechanism of the occurrence of labor pain when one (I) is as follows: First stage pain is mainly caused by a stimulus delivered through the nerves in the cervix (cervix) and lower uterus/uterus. This pain is a visceral pain originating from uterine and anal contractions. Pain intensity is related to the strength of the contraction and the pressure generated. Strong uterine contractions are a source of pain when I feelings of pain and fear of a mother in childbirth vary widely and are influenced by many factors, including differences in social structure, culture, religion, mother's readiness in the face of childbirth, past experiences, family assistance, and environment. Maternal physical condition can be a factor that influences anxiety at first stage of labor. Pregnancy that occurs at the age of $<20$ years and $>35$ years will cause problems [13]. This is in line with research that says that low knowledge can cause a person to experience anxiety and fear easily. Ignorance about something is considered as a pressure that can cause anxiety. This is due to lack of information obtained. As a result that can occur if the mother cannot know the first stage of labor, the mother will feel anxious and can increase pain. If the mother has knowledge about this, then the mother will be more confident in facing labor [13], [14].

Perception and expression of labor pain are influenced by individual culture. Culture influences the mother's attitude during childbirth. According to Nasution et al., 2015 [15], explained that culture affects the health status of mothers from pregnancy to childbirth. It is important for maternity nurses to know how beliefs, values, and cultural practices of a mother in presenting and expressing labor pain [16].

Stress or fear turns out to be physiologically able to cause uterine contractions to become more painful and felt pain. Because when a woman in an inpartu condition experiences stress, the body automatically releases stressor hormones, namely, the catecholamine and adrenaline hormones. This catecholamine will be released in high concentration during labor if the prospective mother cannot eliminate fear and anxiety before giving birth. As a result of the body's response, the uterus becomes increasingly tense so that blood flow and oxygen into the muscles of the uterus are reduced because the arteries shrink and narrow as a result of pain that cannot be tolerated. Relaxing body condition when facing childbirth is very important, if the mother is relaxed then all the muscle layers in the uterus will work together harmoniously as they should so that labor will run smoothly, easily, and comfortably. If the mother is used to relaxation exercises, the birth canal will be more easily open. Conversely, if the mother is in a tense state, the fetal head pressure will not make the cervix open, and only pain and the mother feel more panicked and stressed. Relaxation is one way to overcome anxiety or stress through the relaxation of muscles and nerves. Relaxation can improve general health by facilitating the body's metabolic processes, decreasing the level of aggression and bad behaviors from the effects of stress, increasing self-esteem and selfconfidence, thinking more mature, facilitating self-control, reducing overall stress, and increasing welfare [5].

This relaxation response makes the first stage of labor experience a decrease in anxiety level scores so as to facilitate the delivery process. Progressive muscle relaxation techniques are a relaxation therapy that is given to clients by tensing certain muscles and then relaxing. Progressive relaxation is one way of relaxation techniques combining deep breathing exercises and a series of certain muscle contractions and relaxation [11]. 
Controlled relaxation and breathing can improve the ability to overcome anxiety and increase the sense of being able to control stress and pain. In addition, relaxation also makes the uterine, placental and fetal blood circulation smooth so that your baby's oxygen and food needs are met. Smooth blood circulation will also make the muscles associated with the uterus and fetus such as the pelvic muscles, back, and abdomen become limp and sagging. While during labor, relaxation makes the contraction process safe, natural, and smooth [8]. This has also been proven by research which states that there is an effect of progressive muscle relaxation on decreasing anxiety levels in pre-operative patients [10].

In pre-operative patients with anxiety, the anxiety results in some muscle tension, activating the sympathetic nerves. Relaxation has a calming effect on the limbs, is light, and feels warmth that spreads throughout the body. Changes that occur during and after relaxation affect the work of the autonomic nerves. Emotional responses and calming effects caused by this relaxation turn the sympathetic dominant physiology into a dominant parasympathetic system [5]. In this state, catecholamine and cortisol hypersecretion are reduced and increase parasympathetic hormones and neurotransmitters such as dehydroepinandrosterone and dopamine or endorphins. The regulation of the parasympathetic system eventually causes a calming effect [17].

\section{Conclusions}

The intervention was carried out on mothers undergoing vaginal delivery in the latent phase without complication and data complications showed that there was a complete acceleration in the opening time of labor using progressive muscle relaxation techniques with $p<0.05(p=0.000)$.

\section{References}

1. Rosdahl CB, Kowalski MT. Buku Ajar Keperawatan Dasar. Jakarta: EGC; 2014.
2. Rondung E, Thomtén J, Sundin Ö. Psychological perspectives on fear of childbirth. J Anxiety Disord. 2016;44:80-91. https:// doi.org/10.1016/j.janxdis.2016.10.007

PMid:27788373

3. Jensen BL. Buku Ajar Keperawatan Maternitas. Jakarta: EGC 2004.

4. Prawirohardjo S. IImu Kandungan. $2^{\text {nd }}$ ed. Jakarta: Yayasan Bina Pustaka; 2002.

5. Conrad A, Roth WT. Muscle relaxation therapy for anxiety disorders: It works but how? J Anxiety Disord. 2007;21(3):24364. https://doi.org/10.1016/j.janxdis.2006.08.001 PMid: 16949248

6. Bare S. Buku Ajar Keperawatan Medikal Bedah. Jakarta: EGC 2002.

7. Yuliati T. Efektivitas Metode Relaksasi Pernapasan Pada Nyeri Persalinan Kala I Fase Aktif Di Medan. 2011.

8. Rohani D. Asuhan Kebidanan Pada masa Persalinan. Jakarta: Salemba Medika; 2011.

9. Romano L. Asuhan persalinan and kehamilan. In: Sumarah. Jakarta: EGC; 2010

10. Lestari KP, Yuswiyanti A. The Effect of Progressive Muscle Relaxation on Decreasing Anxiety Levels in Preoperative Patients in the Wijaya Kusuma Room, Rsud Dr. R Soeprapto Cepu. J Keperawatan Matern. 2018;3(1):27-32. https://doi. org/10.32584/jikmb.v2i2.248

11. Herodes. Teknik Relaksasi Progresif Terhadap Insomnia Pada Lansia; 2010. Available from: http://www.herodessolution. blogspot.com/2010/11/teknik-relaksasi-progresif-terhadap.html. [Last accessed on 2017 Feb 20]. https://doi.org/10.32831/jik. v6i2.168

12. Kustanti E, Widodo A. Pengaruh teknik relaksasi terhadap perubahan status mental klien skizofrenia di rumah sakit jiwa surakarta. Berita IImu Keperawatan. 2008;1(3):131-6.

13. Helbig A, Kaasen A, Malt UF, Haugen G. Does antenatal maternal psychological distress affect placental circulation in the third trimester? PLoS One. 2013;8(2):e57071. https://doi. org/10.1371/journal.pone.0057071 PMid:23437312

14. Musbikin I. Persiapan Menghadapi Persalinan dari Perencanaan Kehamilan Sampai Mendidik Anak. Yogyakarta: Mitra Pustaka; 2006.

15. Nasution SS, Badaruddin B, Dasatjipta G, Lubis Z. Effectiveness of the health awareness community team intervention in improving the maternal and neonatal health status in Mandailing natal (Madina) Sumatera Utara Indonesia. Int J Med Sci Public Health. 2015;4(6):799-804. https://doi.org/10.5455/ ijmsph.2015.26022015163

16. Nasution SS, Badaruddin DG, Lubis Z. The effectiveness of the intervention of Sehat Umakna Sehat Anakna towards improving the behaviour, knowledge and attitude of pregnant mother towards maternal and neonatal care in Mandailing Natal Sumatera Utara. Int J Nurs Midwif. 2015;7(11):162-7. https://doi. org/10.5897/ijnm2015.0162

17. Setyoadi K. Terapi Modalitas Keperawatan Pada Klien Psikogeriatrik. Jakarta: Salemba Medika; 2011. 